\title{
Human Endoparasites Present in the Digestive Tracts of Two Species of Cichlidae Fish: Oreochromis Niloticus (Linnaeus, 1758) and Tilapia Tholloni (Sauvage, 1884) Caught in the Malebo Pool (Congo River), D.R. Congo
}

\author{
Victor Pwema Kiamfü ${ }^{1,2}$, Jeff Nakweti K. ${ }^{2}$, Willy Lusasi Swana ${ }^{1,2}$, Santos Kavumbu Mutanda ${ }^{1,2}$, Clement \\ Munganga Kilingwa ${ }^{1,2}$, Theo Mondo Mapasi ${ }^{3,4}$, John Tembeni M. ${ }^{1,2} \&$ Mbomba Bekeli N`seu ${ }^{1,2}$ \\ ${ }^{1}$ Laboratory of Limnology, Hydrobiology and Aquaculture, Department of Biology, Faculty of Sciences, \\ University of Kinshasa (UNIKIN), Democratic Republic of Congo \\ ${ }^{2}$ Department of Biology, Faculty of Sciences, University of Kinshasa (UNIKIN), Democratic Republic of Congo \\ ${ }^{3}$ Laboratory Technology Section, Higher Institute of Medical Techniques of Kinshasa (ISTM/KIN), Democratic \\ Republic of Congo \\ ${ }^{4}$ Department of Environmental Sciences, Faculty of Sciences, University of Kinshasa, Democratic Republic of \\ Congo \\ Correspondence: Willy Lusasi Swana, Laboratory of Limnology, Hydrobiology and Aquaculture, Department of \\ Biology, Faculty of Sciences, University of Kinshasa (UNIKIN), P.O Box 190 Kinshasa XI, Democratic Republic \\ of Congo. Tel: 243-813-662-026. E-mail: willy.lusasi@unikin.ac.cd
}

Received: June 3, 2020 Accepted: July 8, 2020 Online Published: August 11, 2020

\begin{abstract}
Parasitic diseases of fish are very rarely highlighted in comparison with certain parasitic diseases transmitted to humans through animals or plants such as echinococcosis, bilharziasis or fasciolosis. The aim of this study is to provide knowledge on endoparasites of the human digestive tract that also infest the digestive tracts of two species of Cichlidae fish: Oreochromis niloticus Linnaeus, 1758 and Tilapia tholloni Sauvage, 1884 caught in the Congo River (Malebo Pool). Microscopic observations were made on 42 specimens of $O$. niloticus fish and 42 of $T$. tholloni. The results obtained showed that the digestive tracts of fish Oreochromis niloticus host 8 species of parasites grouped in 6 genera, 6 families, 4 classes and 2 branches. The species belonging to the phylum Nemathelminths branch were more abundant (58.8\%) than Plathelminths (41.2\%). Species Trichurus trichiura (23.5\%), Ascaris lumbricoides (20.6\%), Strongyloides stercoralis (14.7\%), Schistosoma haematobium and Schistosoma intercarlantum (11.8\%) were the most frequently observed. On the other hand, microscopic analyses of the digestive tract of Tilapia tholloni revealed the presence of five species of parasites belonging to 3 branches, 4 classes, 4 families and 4 genera. Nemathelminthes (58.3\%) and Plathelminthes (25\%) are the most represented phylum than Amoebians (16.7\%). Enterobius vermicularis (33.3\%), Trichocephalus trichuris (25\%), Schistosoma haematobium (20.8\%) and Entemoeba hystolica (16.7\%) were frequently observed. These results confirm the presence of endoparasites in congolese freshwater fish. This information is important in setting up a strategy to protect fish and consumers against these pathogens.
\end{abstract}

Keywords: Endoparasites, freshwater, Oreochromis niloticus, Tilapia tholloni, Congo River, Malebo Pool, Kinshasa

\section{Introduction}

Aquatic ecosystems provide many goods and services that are often not fully appreciated (Brummett et al., 2008). Water pollution from a variety of natural, domestic, agricultural and industrial causes is the source of many diseases related to infectious or toxic factors (Delolme et al., 1992). Generally, fish from these polluted environments are infested, their consumption could transmit the parasitosis to humans, from which fecal parasites can probably be observed from humans to fish and from fish to humans whose reservoir is the water. According to Thillement (2015), more than 100 pathogens are likely to parasitize humans, but only a small number represent a public health problem. In water, pathogens are easily transmitted from one fish to another through the skin and gills. Fish are sensitive to stress, can be disturbed by poor water quality, poor diet, rough handling or a disturbed 
environment. This can result in a decrease in immune system activity, which can lead to the sudden onset of disease. Fry and juveniles are the most vulnerable; they need to develop their immunity (Edéa et al., 2019).

There is a multitude of possible diseases (parasitic, bacterial, viral, etc.). Stressed fish can often be identified by abnormal behaviour such as decreased appetite, nervous or waddling swimming, upright position at the surface, or by clinical symptoms or pathologies such as morphological abnormalities (barbels or damaged fins, large belly, blocked mouth, goiters, etc.), eye disorders (protruding eyes, glassy eye, loss of eye, etc.) or by the presence of a large number of other diseases. ), gill disorders (degeneration, whiteheads, etc.), internal organ disorders (dark spots on the liver, heart, spleen, inflammation of the intestine; etc.), skin disorders (foamy lips, blackish tumours, etc.), behavioural disorders (fish piping air on the surface, uncoordinated swimming movements, etc.), undesirable hosts (algae, hydrous, chlorinated water, etc.). Nevertheless, these symptoms are not specific, therefore, precise laboratory techniques are required to diagnose the disease (Lacroix, 2004).

In Kinshasa, in the Democratic Republic of Congo, watercourses are considered to be the drain through which all waste is evacuated (faeces, urban, industrial and domestic waste). One third of the fresh fish consumed by the people living along the Congo River in the Pool Malebo comes from artisanal fisheries. Offering consumers fresh fish free of parasites and other types of pollutants is a real challenge, especially since the Congo River is considered a dumping ground by the same population. This situation constitutes a real threat to the human health of Kinshasa's population (Masua et al., 2020; Munganga et al., 2020).

Fish consumption is increasingly important on a global scale: it was $9.9 \mathrm{~kg}$ per capita per year in 1960 and 20.1 kg per capita per year in 2014 (FAO, 2016). Despite its economic and dietary importance, this food is a biotope that is very favourable to the development of a large number of parasites (Nchoutpouen \& Fomena, 2011; Falaise, 2017). Given that fishing is the main activity of the riparian populations of the Malebo Pool (Congo River), this situation is a problem for the maintenance of fish in their ecosystem but also for human health. This study aims to identify human endoparasites in the digestive tracts of two species of freshwater fishes of the family Cichlidae (Oreochromis niloticus Linnaeus, 1758 and Tilapia tholloni Sauvage, 1884) caught in the Malebo Pool (Congo River) in the Democratic Republic of Congo. The results of this study will make it possible to warn the population about the risks incurred following the consumption of fishery products from polluted environments but also to fill the gaps in knowledge of pathogens harmful to human health through the consumption of fish.

\section{Material and Methods}

\subsection{Study Environment}

This study took place in the Malebo Pool (Congo River) at the Kinkole fishing station (figure 1). The Malebo Pool, formerly known as the Stanley Pool, is the widening of the Congo River located at the border between the Democratic Republic of Congo (Kinshasa city province) and the People's Republic of Congo (Brazzaville

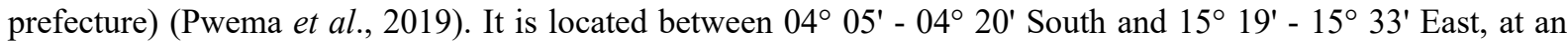
altitude of $275 \mathrm{~m}$. This part of the river is about $35 \mathrm{~km}$ long and $25 \mathrm{~km}$ wide. Its average depth is $3 \mathrm{~m}$ with a maximum of $20 \mathrm{~m}$ and a surface area of $500 \mathrm{~km}^{2}$ (Burgis \& Symoens, 1987; Muzigwa et al., 1994). The Malebo Pool enjoys a hot and humid tropical climate of $\mathrm{AW}_{4}$ type according to the Köppen classification, characterised by two types of seasons: the long rainy season (between September and mid-May) and the dry season (between mid-May and August). The average temperature varies between $22.5^{\circ} \mathrm{C}$ and $25{ }^{\circ} \mathrm{C}$. The hydrography of Pool Malebo includes the Congo River and mainly the N'sele and N'djili rivers which are its tributaries (Mbadu, 2001; Munganga et al., 2020). 


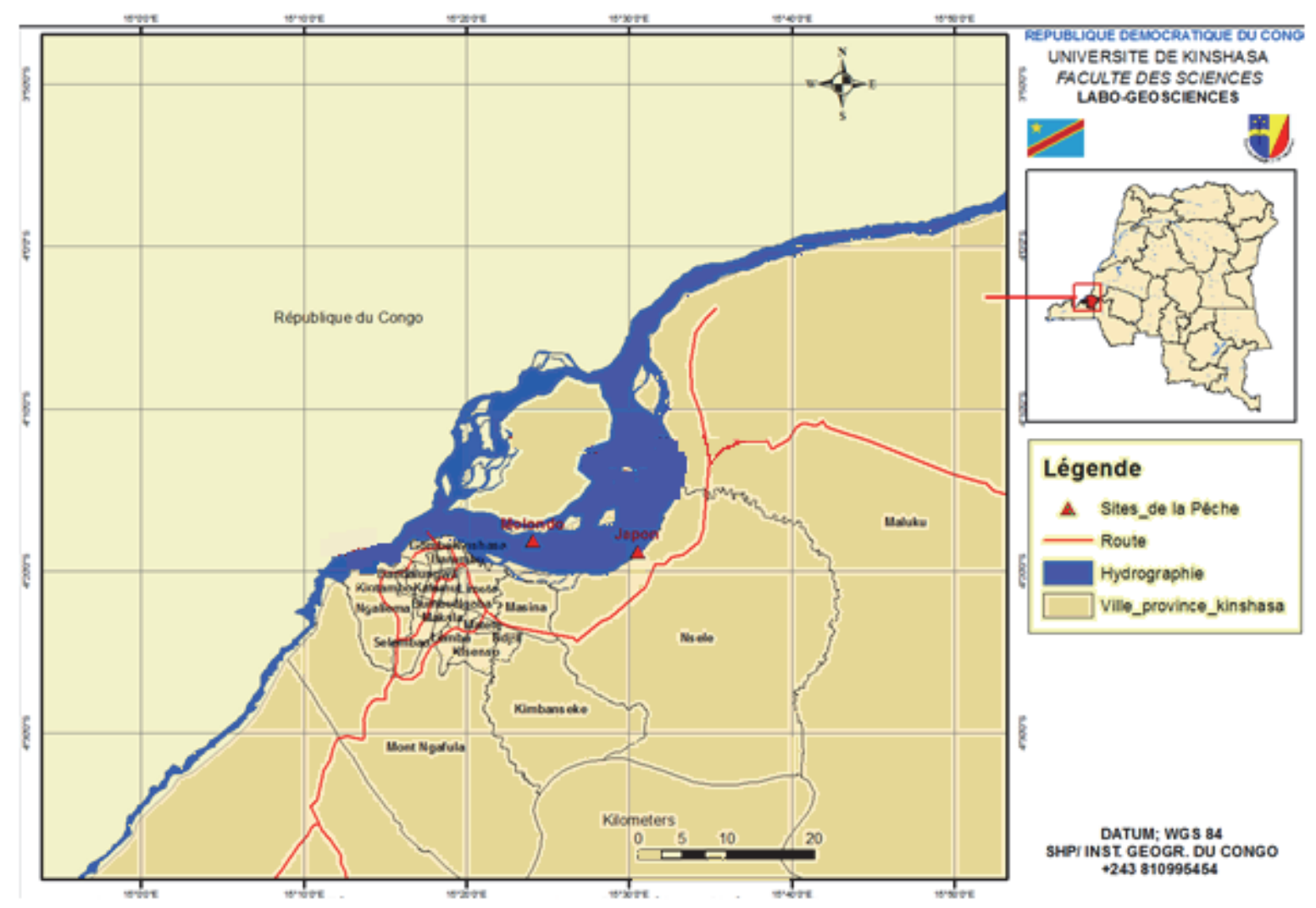

Figure 1. Map of the Malebo Pool (Congo River) showing the fishing sites at the Kinkole station

\subsection{Methodology}

\subsubsection{Fish Data Collection and Laboratory Handling}

The fish specimens Oreochromis niloticus Linnaeus, 1758 and Tilapia tholloni Sauvage, 1884 were caught in the Malebo Pool (Congo River) at the Kinkole station $\left(04^{\circ} 18^{\prime}, 26^{\prime \prime} \mathrm{S}, 15^{\circ} 30^{\prime}, 33^{\prime \prime} \mathrm{E}\right)$ located in the commune of N'sele. Specimens were collected monthly for 6 months between January and June 2017. The catches were obtained by artisanal fisheries while using hawks nets of $2 \mathrm{~cm}$ mesh size and $5 \mathrm{~m}$ in diameter. One hundred and six (106) specimens (juveniles and adults) of Cichlidae fish, consisting of 42 individuals Oreochromis niloticus Linnaeus, 1758 and 64 Tilapia tholloni Sauvage, 1884. These fish were caught during artisanal fishing campaigns using a hawksbill net with a mesh size of $2 \mathrm{~cm}$ and $5 \mathrm{~m}$ in diameter. After fishing, the specimens were kept in $10 \mathrm{~kg}$ plastic bags and then placed in a glacier to facilitate their transport to the laboratory. The date of sample collection was marked on each batch of specimens and kept cold in a freezer.

The fish caught were identified using identification keys proposed by Boulenger (1911); Poll (1939a \& b, 1959); Poll \& Gosse (1995a et b) available at the Limnology, Hydrobiology and Aquaculture Laboratory of the Biology Department of the Faculty of Sciences of the University of Kinshasa. The fish were measured (with an electronic ichthyometer, Digital Caliper 200 mm-8 mark) according to Lévêque et al., (1990 \& 1992) and weighed (with an electronic balance, Salter mark) to the nearest millimetre and gram respectively. For size accuracy of the specimens of Oreochromis niloticus and Tilapia tholloni studied, the size class of the fish was calculated according to Sturge's rule (Pwema, 2014).

\subsubsection{Measurement of Environmental Parameters}

Measurements of the environmental variables (temperature $\left({ }^{\circ} \mathrm{C}\right)$, conductivity $(\mu \mathrm{S} / \mathrm{cm})$, turbidity (NTU: Nephelometric Turbidity Unit) and $\mathrm{pH}$ ) were carried out at each sampling site with the HANNA pH/ORP/EC/DO No. HI 9828 multiparameter Combo pH meter probe. 


\subsubsection{Investigation and Identification of Intestinal Endoparasites}

The fish were dissected to isolate the intestines, which were first examined with the naked eye and then with a binocular magnifying glass (Olympus brand TOKYO 323693). Each digestive tract thus isolated was placed in a pre-numbered glass vial containing 4 drops of physiological water. Fresh smears of fragments of these stomach contents were observed with a Euromex photomicroscope at the laboratory of the Mont-Amba hospital center. The endoparasites observed were identified using the identification guide for intestinal parasites proposed by WHO (1994). This identification was done at the species level.

\subsubsection{Statistical Analysis and Data Processing}

The various data were analysed and encoded on the Excel 2010 spreadsheet. The results obtained after treatment were expressed in the form of tables, graphs and figures to facilitate their interpretation. Origin 6.1 software was used to generate the graphs.

\section{Results}

\subsection{Physico-Chemical Parameters of Water}

Table 1. Physico-chemical parameters of the waters of the Congo River at Kinkole

\begin{tabular}{lllll}
\hline Sites & Température $\left({ }^{\circ} \mathrm{C}\right)$ & Conductivity $(\mu \mathrm{S} / \mathrm{cm})$ & Turbidity $(\mathrm{ppm})$ & $\mathrm{pH}$ \\
\hline I & $29,3 \pm 0,13$ & $27,9 \pm 0,97$ & $13,73 \pm 0,1$ & $6,27 \pm 0,11$ \\
II & $28,9 \pm 0,18$ & $27,5 \pm 0,83$ & $14,21 \pm 0,38$ & $6,62 \pm 0,28$ \\
Mean & $29,1 \pm 0,2$ & $27,7 \pm 0,2$ & $13,97 \pm 0,24$ & $6,44 \pm 0,17$ \\
\hline
\end{tabular}

The results of the environmental parameters shown in table 1 above show that the surface water of the Congo River in the Malebo Pool has an average temperature of $29.1 \pm 0.2{ }^{\circ} \mathrm{C}$ and is low in mineral salts (average conductivity equal to $27.7 \pm 0.2 \mu \mathrm{S} / \mathrm{cm}$ ). This water is slightly turbid at the sampling sites and has an average turbidity of $13.97 \pm 0.24 \mathrm{ppm}$. The hydrogen potential shows that this water is slightly acidic (pH: 6.44 \pm 0.17 ).

\subsection{Fish Size Classes}

Table 2. Different size classes of fish specimens studied

\begin{tabular}{llll}
\hline Species of fish & Size classes & Size range $(\mathrm{mm})$ & Number of fish \\
\hline & I & {$[64,3-98,3[$} & 6 \\
& II & {$[99-133[$} & 5 \\
& III & {$[134-168[$} & 6 \\
& IV & {$[169-203[$} & 10 \\
& V & {$[204-238[$} & 9 \\
Oreochromis niloticus & VI & {$[239-273[$} & 15 \\
& VII & {$[274-308,1[$} & 13 \\
& Total & & 64 \\
& I & {$[66,4-104,4[$} & 5 \\
& II & {$[105-143[$} & 7 \\
& III & {$[144-182[$} & 4 \\
& IV & {$[183-221[$} & 9 \\
Tilapia tholloni & V & {$[222-260[$} & 7 \\
& VI & {$[261-298,3[$} & 10 \\
& Total & & 42 \\
\hline
\end{tabular}


The size classes of the different specimens of Oreochromis niloticus and Tilapia tholloni studied were established according to Sturge's rule. A total of 64 specimens of $O$. niloticus fish were grouped into 7 size classes. The sixth class (size range: $239 \mathrm{~mm}$ to $273 \mathrm{~mm}$ ) is the one with a large number of individuals (i.e. 15 fish) and the second class (size range: $99 \mathrm{~mm}$ to $133 \mathrm{~mm}$ ) has fewer specimens (i.e. 5 individuals). The fish Tilapia tholloni has 42 specimens grouped in six size classes, of which the sixth class (size between $261 \mathrm{~mm}$ and $298.3 \mathrm{~mm}$ ) has the majority of fish (i.e. 10 specimens) and the third class (size range: $144 \mathrm{~mm}$ to $182 \mathrm{~mm}$ ) has fewer fish (i.e. 4 individuals).

\subsection{Parasites Observed in the Stomach Contents of the Fish Studied}

\subsubsection{Oreochromis Niloticus Linnaeus, 1758}

Table 3. Endoparasites identified in the digestive tract of fish Oreochromis niloticus

\begin{tabular}{lllll}
\hline Phylum & Class & Family & Genus & Species \\
\hline \multirow{2}{*}{ Némathelminthes } & Adenophorea & Trichuridae & Trichocephalus & Trichocephalus trichiurus \\
& & Ascarididae & Ascaris & Ascaris lumbricoides \\
Plathelminthes & Cestode & Taenidae & Taenidae spp & Taenidae spp \\
& Trématode & Schistosomidae & Schistosoma & Schistosoma mensoni \\
& & & & S. intercalantum \\
& & & S. haematobium \\
& & Tronglomatidae & Paragonimus & Paragonimus westermani \\
& & 6 & 6 & 8 \\
\hline
\end{tabular}

Microscopic observations made on 42 digestive tracts of Oreochromis niloticus fish reveal the presence of 8 species of endoparasites that have infested these poisons. These parasites are divided into 6 genera, 6 families, 4 classes and 2 branches. Of the 42 digestive tracts of fish analysed, only 32 are positive and 10 others are not infested.

\subsubsection{Relative Abundance of Branches of the Identified Endoparasites}

The majority of the Oreochromis niloticus fish analysed are infested by endoparasites of the Nemathelminthes phylum (58.8\%) than the Plathelminthes phylum (41.2\%) (figure 2).

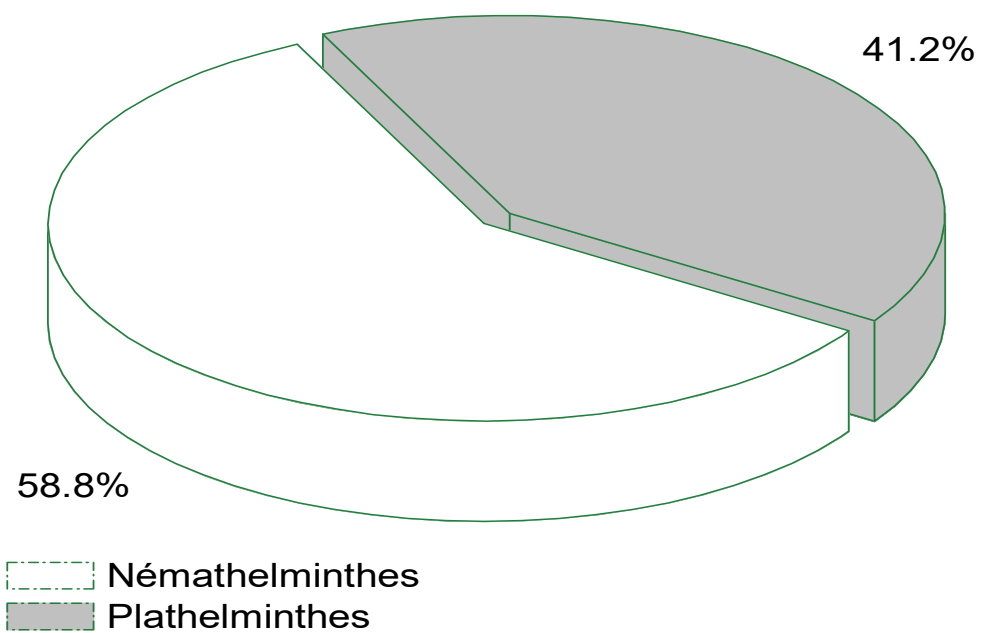

Figure 2. Relative abundance of the orders of parasites identified in the digestive tract of fish Oreochromis niloticus 


\subsubsection{Relative Abundance of the Genera of the Identified Pests}

Of all the genera of endoparasites identified in the digestive tract of fish Oreochromis niloticus, those of the genus Schistosoma are in the majority (with 37.5\%) and those of the genera Ascaris, Strongloides, Taenia spp and Pragonimus are in the minority (representing $12.5 \%$ respectively) (figure 3 ).

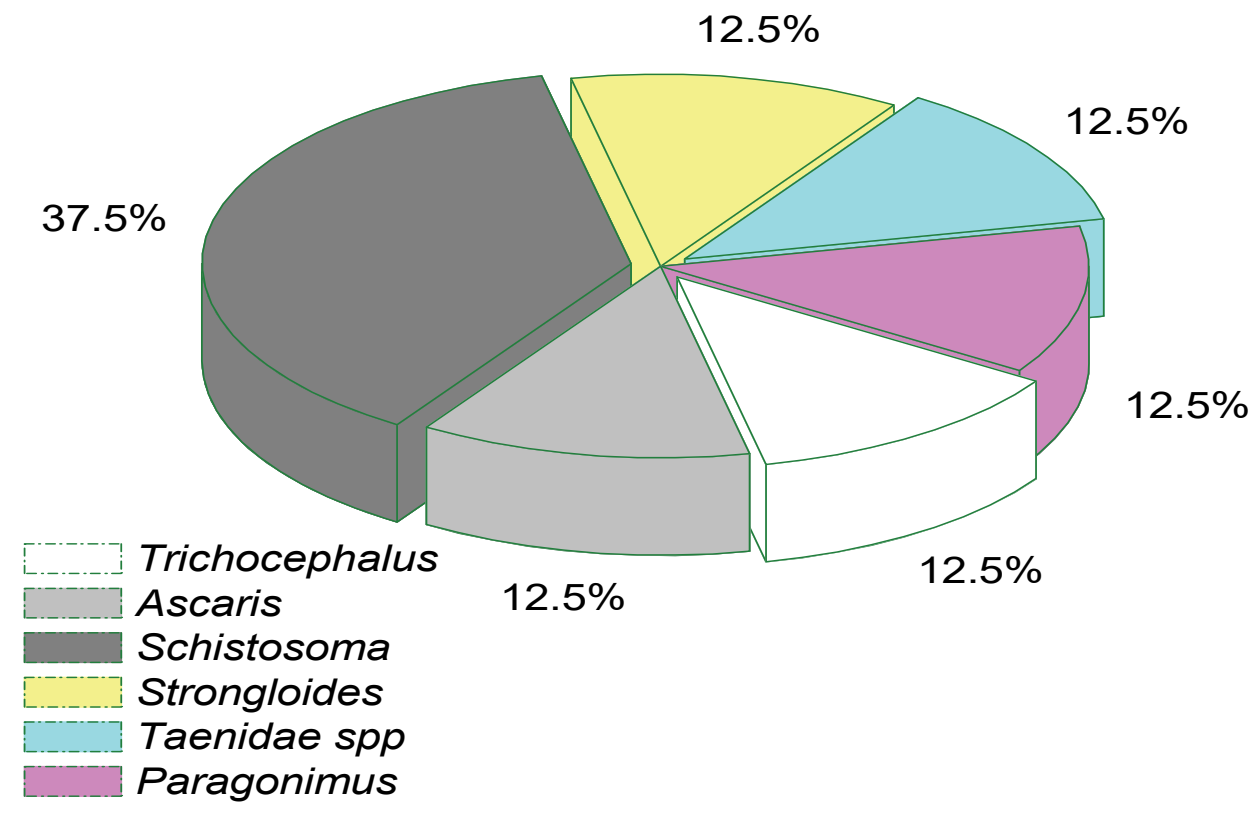

Figure 3. Relative abundance of the genera of parasites identified in the digestive tract of fish Oreochromis niloticus

\subsubsection{Relative Abundance of Identified Endoparasite Species}

Trichurus trichiura $(23.5 \%)$ is the most common endoparasite found in the digestive tracts of fish analysed. Ascaris lumbricoides (20.6\%) came second followed by Strongyloides stercoralis (14.7\%), Schistosoma haematobium and Schistosoma intercarlantum (with $11.8 \%$ respectively). Schistosoma mensoni accounts for $9 \%$ while Taenia spp was analysed at $5.9 \%$ and Paragonimus westermani at $2.9 \%$ (figure 4).

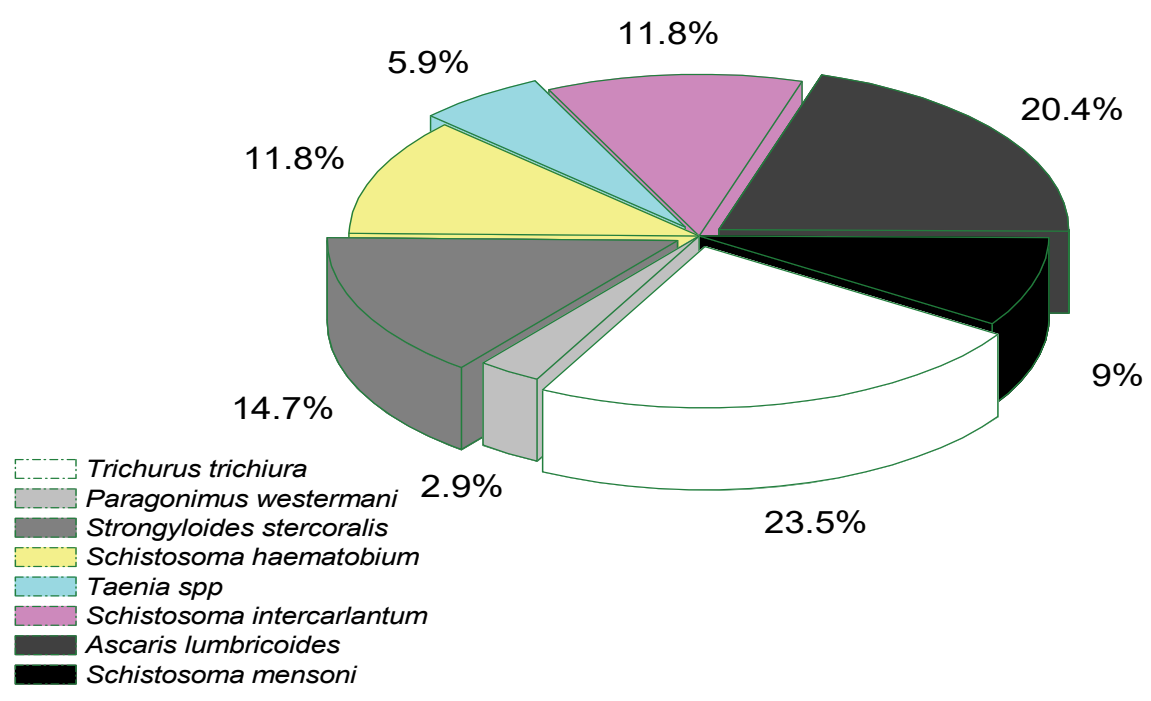

Figure 4. Relative abundance of species of parasites identified in the digestive tract of fish Oreochromis niloticus 


\subsubsection{Tilapia tholloni Sauvage, 1884}

Table 4. Parasites identified in the digestive tract of fish Tilapia tholloni

\begin{tabular}{cllll}
\hline \multicolumn{1}{c}{ Phylum } & \multicolumn{1}{c}{ Class } & \multicolumn{1}{c}{ Family } & \multicolumn{1}{c}{ Genus } & \multicolumn{1}{c}{ Species } \\
\hline \multirow{2}{*}{ Amoebiens } & Lobosea & Amiboidae & Entamoeba & Entamoeba histolyca \\
& Adenophorea & Trichuridae & Trichocephalus & Trichocephalus trichiurus \\
\hline Némathelminthes & Secernetea & Oxyuridae & Enterobius & Enterobius vermicumlaris \\
\hline \multirow{3}{*}{ Plathelminthes } & Trématode & Schistosomidae & Schistosoma & $\begin{array}{l}\text { Schistosoma } \\
\text { haematobium } \\
\text { S. intercalantum }\end{array}$ \\
& & & $\mathbf{4}$ & $\mathbf{5}$ \\
\hline $\mathbf{3}$ & $\mathbf{4}$ & $\mathbf{4}$ & $\mathbf{4}$ &
\end{tabular}

Microscopic analyses of the stomach contents of Tilapia tholloni fish reveal that their digestive tracts are infested with 3 branches, 4 classes, 4 families, 4 genera and 5 species of endoparasites. Of the 42 fish specimens analysed, the digestive tracts of 23 were positive and 9 others showed no evidence of endoparasites.

\subsubsection{Relative Abundance of Branches of the Identified Parasites}

Figure 5 below shows that the digestive tracts of Tilapia tholloni fish are mostly infested by Nemathelminths (58.3\%), followed by Plathelminths (25\%) and Amoebians are less abundant (16.7\%).

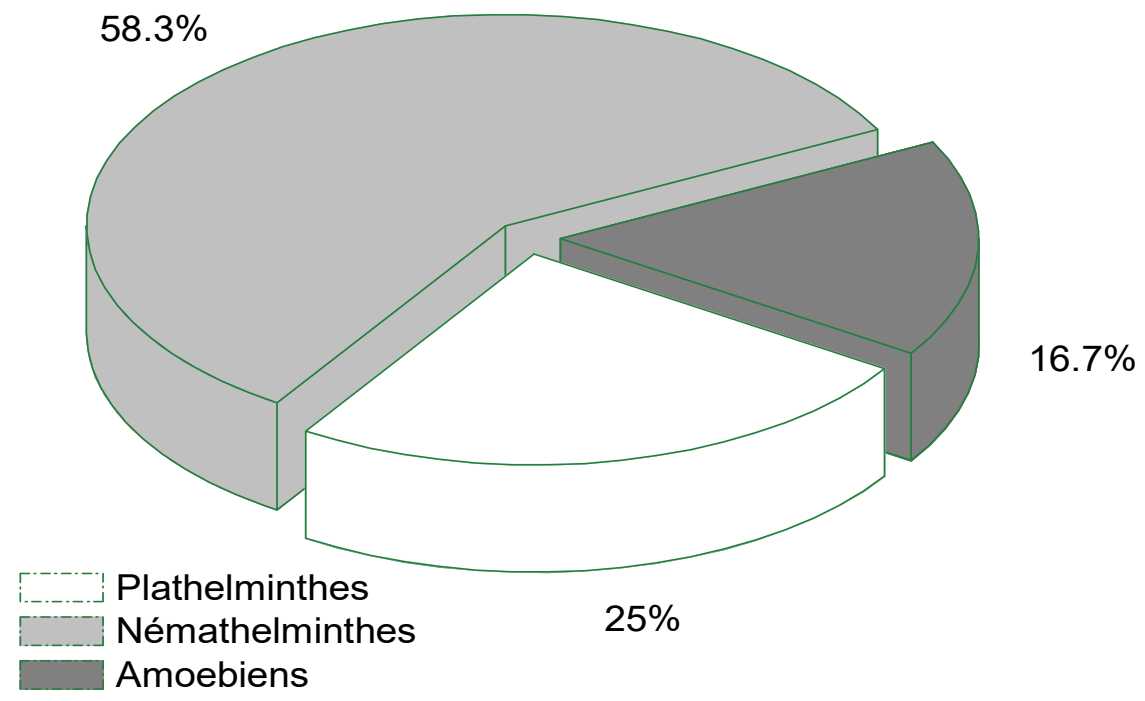

Figure 5. Relative abundance of branches of the parasites identified in the stomach contents of fish Tilapia tholloni

\subsubsection{Relative Abundance of the Genera of the Identified Pests}

Endoparasites of the genus Schistosoma infest the majority of the Tilapia tholloni fish analysed (i.e. 40\%), followed by those of the genera Entamoeba, Trichocephalus and Enterobius (with 20\% respectively) (figure 6). 


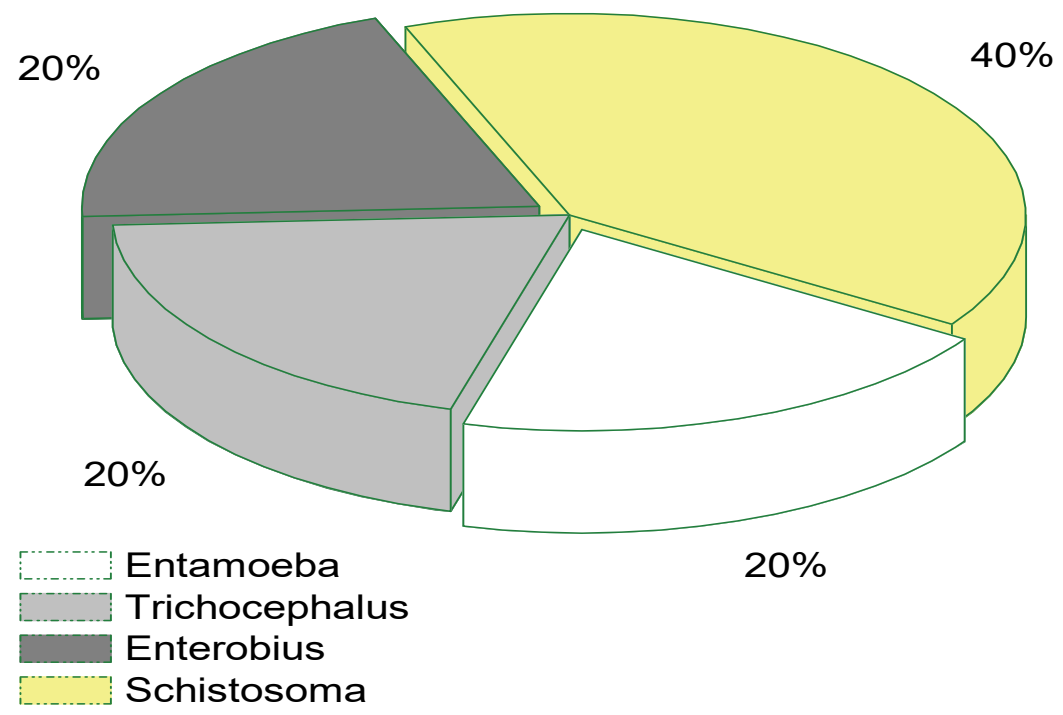

Figure 6. Relative abundance of the genera of parasites identified in the stomach contents of fish Tilapia tholloni

\subsubsection{Relative Abundance of Species of Identified Parasites}

In the digestive tract of Tilapia tholloni fish, Enterobius vermicularis is the most common species (33.3\%), followed by Trichocephalus trichuris (25\%), Schistosoma haematobium (20.8\%), Entamoeba hystolica (16.7\%) and Schistosoma intercalantum (4.2\%) (figure 7).

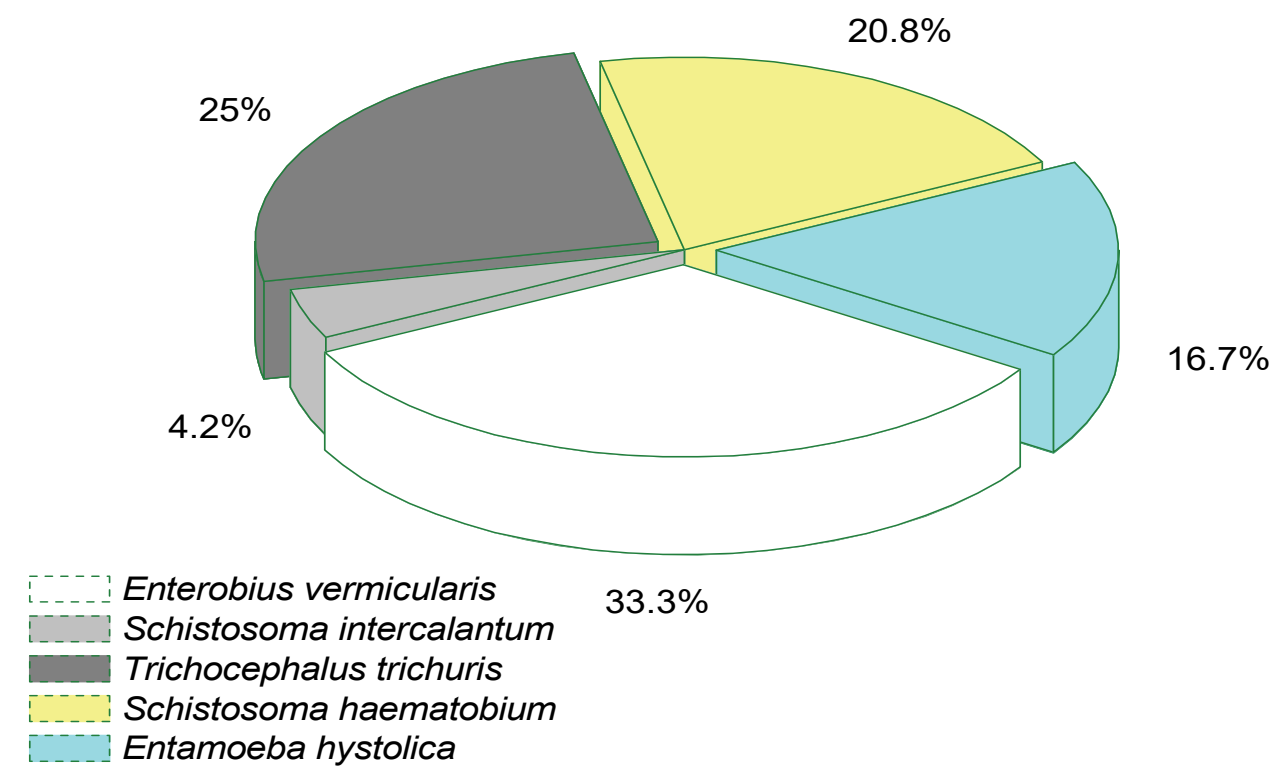

Figure 7. Relative abundance of species of parasites identified in the stomach contents of fish Tilapia tholloni

\section{Discussion}

The results obtained on environmental variables of the fishing sites showed that the water of the Congo River has an average temperature of $29.1 \pm 0.2^{\circ} \mathrm{C}$, with a low amount of dissolved mineral salts. This water is slightly cloudy and had a low content of suspended matter. Hydrogen potential analysis showed that this water is slightly acidic. These observations meet those made by several authors who have exploited this part of the Congo River (Mbadu, 2011; Pwema, 2014; Tembeni et al., 2019). Climate has a definite impact on infestation in temperate or tropical 
zones since the intermediate hosts are ectothermal (Van Cam, 2009; Falaise, 2017). However, thermal comfort zones are sometimes minimal and depend on the species. Petney et al., (2013) state that the rate of infestation of fish by metacercariae of Opisthorchiidae varies from year to year depending on the season, age and species of the fish, geographical area, aquatic habitat and climatic factors (intensity of rainfall). Results of research conducted by Madsen et al., (2015) in Vietnam showed that the peak of transmission of endoparasites to fish was during the summer (May to November), particularly during the period of heavy rainfall. The prevalence and intensity of infection then decreases in winter (December-January) due to lower water levels and colder temperatures. Snails are infected but the release of cercariae into the water is slowed down. Thailand is a tropical country, the peak of faecal contamination in aquatic environments and the peak of contamination of snails by Opisthorchis viverrini occurs at the time of flooding. The peak of human transmission occurs just after the monsoon (October to February), when intermediate host fish are abundant and heavily parasitized. In countries with a marked cold season, peak transmission occurs during the warmer months. Indeed, the accommodation of cercariae in snails is dependent on water temperature (Falaise, 2017). In China, a study has shown that the risk of human infestation by Clonorchis sinensis would be greater in case of high temperatures and rainfall, but too high ambient humidity would reduce this risk (Li et al., 2014). Thus, the different values of physico-chemical parameters recorded in the Congo River favour the maintenance of endoparasites in this aquatic ecosystem.

Microscopic observations of the digestive tracts of fish specimens Oreochromis niloticus and Tilapia tholloni revealed the presence of several species of intestinal endoparasites capable of infesting humans. The digestive tracts of fish $O$. niloticus were infested with eight species of endoparasites in six genera, six families, four classes and two phyla (Nemathelminths and Plathelminths). In terms of frequency of occurrence of endoparasitic species, Trichurus trichiura (23.5\%), Ascaris lumbricoides (20.6\%), Strongyloides stercoralis (14.7\%), Schistosoma haematobium and Schistosoma intercarlantum (11.8\%) were the most common. On the other hand, microscopic analyses carried out on the digestive tracts of Tilapia tholloni specimens revealed the presence of 3 branches (Nemathelminthes, Plathelminthes and Amoebians), 4 classes, 4 families, 4 genera and 5 species of endoparasites that had infested the digestive tracts of these fish. It was found that, Enterobius vermicularis (with 33.3\%), Trichocephalus trichuris (with 25\%), Schistosoma haematobium (with 20.8\%) and Entamoeba hystolica (with $16.7 \%$ ) were frequently observed. These results are close to those obtained by Kulenduka (2015); Mondombi (2015) during research on endoparasites of the digestive tracts of certain fish in the Malebo Pool (Congo River).

Kulenduka (2015) examined the endoparasites of the fish Oreochromis niloticus in the Malebo Pool by reporting 6 species, 6 genera, 6 families, 5 classes and 3 branches of endoparasites. In addition, Mondombi (2015) analysed 5 species, 6 genera, 5 families, 3 classes and 2 branches of parasites in the digestive tracts of Brycinus imberi fish caught at the Maluku station in the Malebo Pool (Congo River). In contrast to the latter, the high proportion of parasite species observed during our analyses can be explained by the poor hygienic conditions at the Kinkole fishing station. We noticed that at the fishermen's boat sites where the fish harvesters buy, clean, gut and sell fresh fish and other fishery products, some other human activities such as washing, swimming, dumping household waste and even human and farm animal excreta are carried out. The massive presence of travellers in this fishing site waiting to reach the provinces of Mai-Ndombe, Kwilu, Equateur, Mongala, northern Ubangi and so many others by sea is remarkable. While waiting for their departure, the latter contribute to the pollution of the river waters by the discharge of all kinds of waste (liquid and solid) and consider the Congo River as a septic tank by depositing faecal matter there during their stay and journey. These activities and behaviours cause secondary contamination of the Congo River. Durand and Lévêque (1980) consider that most of the anthropic activities carried out along the countries' aquatic ecosystems constitute a real threat to aquatic resources, including fish. The presence of Trichocephalus trichuris, Entamoeba hystolica and Enterobius vermicularis is linked to faecal matter and that of species of the Schistomidae family is due to water contamination by the discharge of various household wastes.

The presence of the different species of endoparasites identified in the digestive tract of fish Oreochromis niloticus and Tilapia tholloni is explained by the ingestion of water and food contaminated by different types of the parasites in the fish food chain (Edéa et al., 2019). Fish are intermediate hosts for most endoparasites (Nchoutpouen \& Fomena, 2011; Koné, 2015; Falaise, 2017). Following the development cycle of endoparasites, humans are in the majority of cases the final host where these pathogens develop and multiply. In humans, Trichurus trichiura is responsible for Trichocephalosis, Ascaris lumbricoides is the basis of Ascariasis and Strongyloides stercoralis is responsible for Anguillulose or Strongyloidosis. On the other hand, intestinal amoebiasis is caused by Entamoeba hystolica, pinworm is caused by Enterobius vermicularis, Trichocephalus trichuris is responsible for trichocephalosis and endoparasites of the genus Schistosoma are at the base of bilharziosis. These results confirm 
the claims made by Gambari (2013); Mondombi (2015) on the prevalence of parasitic diseases in Sub-Saharan Africa in general and in the Democratic Republic of Congo in particular (Kulenduka, 2015).

\section{Conclusion}

This study showed that the fish Oreochromis niloticus Linnaeus, 1758 and Tilapia tholloni Sauvage, 1884 caught at Kinkole in the Malebo Pool (Congo River) are carriers of endoparasites. These organisms belong to several branches, classes, families, genera and species. The accumulation of Trichurus trichiura, Ascaris lumbricoides, Strongyloides stercoralis, Entamoeba hystolica, Enterobius vermicularis, Trichocephalus trichuris and Schistosoma $s p$ in fish constitutes a health hazard for consumers since fish, like other fishery products, are capable of transmitting microbial and parasitic infections to humans. In order to decrease the parasite load and reduce the risk of infestation by humans and aquatic ecosystems, the authorities of the country are called upon to take adequate measures to protect fish species. We advise the population of Kinshasa bordering the Congo River in the Malebo Pool to clean (eviscerate) immediately and freeze fish at $2^{\circ} \mathrm{C}$ after fishing to avoid post-mortem migration of larvae of endoparasites from the viscera to the muscles. Thorough cooking of fresh fish before consumption remains the best solution to avoid probable endoparasite infestation.

\section{Acknowledgements}

A big thank you to the fishermen of the Malebo Pool including Mr. Héritier LOFONGOLA for his help during the fishing campaigns. The authors also thank all the technicians of the laboratory of the Mont-Amba Hospital Center for their assistance during the microscopic observations of the digestive tracts of fish.

\section{References}

Boulenger, G. A. (1911). Catalogue of fresh water fishes of Africa. British Museum (Natural History), London, (2), $529 \mathrm{p}$.

Burgis, J. M., \& Symoens, J. J. (1987). Zones humides et les lacs peu profonds, d'Afrique. ORSTOM, 211, 560.

Delolme, H. J., Boutin P., \& André L. J. (1992). Eau douce et pathologie. Médecine d'Afrique noir, 39(3), 1-6.

Durand, J. R., \& Lévêque, C. (1980). Les poissons d'eau douce les plus connus du Congo Belge, 34(1-2), 134148.

Edéa, O. G., Hinvi, L. C., Abou, Y., \& Gbangboche, A. B. (2019). Synthèse bibliographique sur des paramètres biologiques et zootechniques du poisson-chat Africain Clarias gariepinus Burchell, 1822. European Scientific Journal, 15(27), 54-88. https://doi.org/10.19044/esj.2019.v15n27p54

Falaise, P. (2017). Les parasites de poisson: agents de zoonoses. Thèse d'exercice, Ecole Nationale Vétérinaire de Toulouse, Université Paul-Sabatier de Toulouse, France, 248 p.

FAO. (2016). The State of World Fisheries and Aquaculture 2016. Contributing to food security and nutrition for all [en ligne]. Rome: FAO. 200 p. ISBN 978-92-5-109185-2. Retrieved from http://www.fao.org/documents/card/en/c/2c8bcf47-2214-4aeb-95b0-62ddef8a982a/. Consulté le 08 Mars 2017.

Gambari, G. (2013). Prévalence des parasitoses intestinales et connaissances attitudes-pratiques des populations péri-urbaines face aux parasitoses intestinalis. Retrieved from www.memooireonline.com/01/14/8537/mprevalence-des-parasitoses-intestinales-et-connaissances-attitudes-pratiques-des-populations-peri32.htlm. Consulté le 22/04/2017.

Koné, M. (2015). Biosécurité en pisciculture et traitements contre le parasite Argulus sp. pour une amélioration de la production du tilapia du Nil Oreochromis niloticus (Linneaus, 1758) de Côte d'Ivoire. Thèse de doctorat, Université de Nangui Abrogoua, Cote d'Ivoire, 233 p. https://doi.org/10.13140/RG.2.1.4974.7042

Kulenduka, M. (2015). Contribution à l'étude des endoparasites de poissons Oreochromis niloticus pêchés dans le Pool Malebo à Kinkole. Mémoire de de licence en sciences biologiques, Université de Kinshasa, R.D Congo, $23 \mathrm{p}$.

Lacroix, E. (2004). Pisciculture en zone tropicale. MAEP-Direction de la Programmation et de la Prospective (2011). Analyse économique des chaînes de valeurs des filières poisson et crevette. GTZ, GFATerra Systems, Hamburg, $231 \mathrm{p}$.

Lévêque, C., Paugy, D., \& Teugels, G. G. (1990 et 1992). Faune des poissons d'eaux douces et saumâtres de l'Afrique de l'Ouest. Edition ORSTM, Tome 1 et 2, Paris, 902.

Li, T., Yang, Z., \& Wang, M. (2014). Correlation between Clonorchiasis incidences and climatic factors in 
Guangzhou, China. Parasites \& Vectors, 7, 29.

Madsen, H., Dung, B. T., The, D. T., Viet, N. K., Dalsgaard, A., \& Van P. T. (2015). The role of rice fields, fish ponds and water canals for transmission of fish-borne zoonotic trematodes in aquaculture ponds in Nam Dinh Province, Vietnam. Parasites \& Vectors, 8, 1-11.

Masua, T. B., Lusasi, S. W., Munganga, K. C., Wumba, M. P., Kavumbu, M. S. \& Pwema, K. V. (2020). Inventory of fresh fish marketed in the markets of Kinshasa in the Democratic Republic of Congo (case of the Gambela and Matete markets). International Journal of Applied Research, 6(4), 102-108.

Mbadu, Z. V. (2011). Biologie des espèces du genre Distichodus Müller et Troschel, 1845 (Distichodontidae, Pisces) du Pool Malebo (fleuve Congo) en rapport avec les mécanismes d'exploitation de leurs niches trophiques. Thèse de doctorat en Sciences Biologiques, Université de Kinshasa, R.D Congo, 442 p.

Mondombi, M. (2015). Etude des endoparasites chez Brycinus imberi dans le fleuve Congo à Maluku. Mémoire de licence en sciences biologiques, Université de Kinshasa, R.D Congo, 28 p.

Munganga, K. C., Lusasi, S. W., \& Pwema, K. V. (2020). Evaluation de la qualité écologique de la rivière Musolo à Kinshasa: Basée sur les macroinvertébrés benthiques en République Démocratique du Congo. Editions Universitaires Européennes, ISBN: 978-613-8-9503-1, 96 p.

Muzigwa, K., Philippart, J. C., \& Mutambue S. (1994). Structure et organisation de la faune piscicole pêchée aux environs de Kinshasa entre Maluku et Kinsuka. Soc. Zoologique de France, Actes du Colloque de Nancy, 153.

Nchoutpouen, E., \& Fomena, A. (2011). Description de trois espèces nouvelles de Myxobolus (Myxosporea: Myxobolidae) parasites de Labeo parvus Boulenger, 1902 (Cyprinidae) au Cameroun. Journal of Applied Biosciences, 38, 2508-2517.

OMS. (1994). Planches pour le diagnostic des parasites intestinaux. Suisse, Genève, 23p.

Petney, T. N., Andrews, R. H., Saijuntha, W., Wenz-Mücke, A., \& Sithithaworn, P. (2013). The zoonotic, fish-borne liver flukes Clonorchis sinensis, Opisthorchis felineus and Opisthorchis viverrini. International Journal for Parasitology, 43, 1031-1046.

Poll, M. (1939a). Au sujet d'une collection des poissons du Stanley-Poll. Ass. Fr. Av. Sc, 669-673.

Poll, M. (1939b). Les poissons du Stanley-Poll. Ann Mus. Congo. Zool, 1(4), 60.

Poll, M. (1959). Recherches sur la faune ichthyologique de la région du Stanley Pool. Annales du Musée Royal du Congo Belge, Tervuren. Série in So Sciences Zoologiques, 71, 75-174.

Poll, M., \& Gosse, J. P. (1995a). Généra des poissons d'eaux douces de l'Afrique. Classe des sciences, Académie Royale de Belgique, 324 p.

Poll, M., \& Grosse, J. P. (1995b). Contribution à l'étude systématique de la faune ichthyologique du Congo central. Annales Musée Royal de l'Afrique Centrale, Tervuren. Série in S0, Sciences Zoologiques, 116, 43-110.

Pwema, K. V. (2014). Ecologie alimentaire, reproduction et mode d'adaptation de cinq espèces de Labeo Cuvier, 1817 dans les milieux lentique et des rapides au Pool Malebo dans le fleuve. Thèse de doctorat en sciences biologiques, Université de Kinshasa, R.D Congo, 163 p.

Pwema, K. V., Mbomba, B. N., Kikala, A. E., Lusasi, S. W., \& Micha, J. C. (2019). Utilisation des Alevins de Schilbe mystus (Linnaeus, 1758) (Siluriformes: Schilbeidae) dans la Lutte Biologique contre les Larves de Moustiques. Congo Sciences, 7(2), 81-86.

Tembeni, M. K., Mbomba B., Micha J. C., \& Mbadu, V. (2019). Spatio-temporal structure of fish communities Mochokidae (Ostariophysi, Siluriformes) en the Malebo Pool, Congo River (Démocratique République of Congo). African Journal of Aquatic Science, 44(4), 377-388.

Thillement, D. (2015). La contamination parasitaire liée à la consommation des viandes, poissons et végétaux dans elles pays industrialisés. Thèse, université de Loraine, France, 129 p.

Thumitho, U. J. P., Mambo, T. M., Urom, C. C., Ngab’u, C. J., Kankonda, B. A., Ulyel, A. P. J., Ngemale, G. M., \& Ngbolua, K. N. (2016). Ecologie alimentaire de Ichtyoborus besse congolensis Giltay, 1930b (Teleostei: Distichodontidae) de rivière Biaro et son affluent Yoko dans la Réserve forestière de Yoko (R.D Congo). International Journal of Innovation and Scientific Research, 21(2), 330-341.

Van Cam A. (2009). La pisciculture en Polynésie française: étude bibliographique et expérimentale des maladies et de leur gestion sanitaire. Thèse de doctorat, Université Claude-Bernard Lyon 1, France, 195 p. 


\section{Copyrights}

Copyright for this article is retained by the author(s), with first publication rights granted to the journal.

This is an open-access article distributed under the terms and conditions of the Creative Commons Attribution license (http://creativecommons.org/licenses/by/4.0/). 